\title{
Violence as a Cultural Process
}

\section{Cliff Leek ${ }^{1}$}

Sociological efforts to understand human action have either explicitly excluded violence from their analysis or have dealt with violence only peripherally. Those approaches that directly address violence tend to view it as structural or systematic rather than as a cultural process. The approach proposed here infuses existing notions of cultural violence, motivation, justification, and answerability with feminist theories of intersectionality and assemblages to form an analytical lens which addresses the weaknesses that arise when these theories are utilized independently. Most importantly, this approach for analyzing violence focuses on the phenomenon of violence as a process rather than as a singular moment. This article theorizes violence as a cultural process then considers the application of that theory in the context of three distinct phenomena: male perpetration of sexual violence against women, the involvement of Reserve Police Battalion 101 in the Holocaust in Poland, and the ongoing drone war in Pakistan. [Article copies available for a fee from The Transformative Studies Institute. E-mail address: journal@transformativestudies.org Website: http://www.transformativestudies.org (C2016 by The Transformative Studies Institute. All rights reserved.]

KEYWORDS: Violence, Justification, Motivation, Feminist Theory.

\section{INTRODUCTION}

Violence is a complex form of human action embroiled not only in systems of justification but dependent also on habitus, schema

\footnotetext{
${ }^{1}$ Cliff Leek is a Ph.D. student in the Department of Sociology at Stony Brook University (SUNY), the MARC (Men Advocating Real Change) Research Fellow with Catalyst Inc., and Managing Editor of the journal Men and Masculinities. He has worked as Prevention Specialist for the Oregon Attorney General's Sexual Assault Task Force and as a consultant for a variety of gender-focused non-profits. Cliff is currently writing his dissertation on the growth patterns and effectiveness of organizations seeking to engage men and boys in gender justice work around the world. Address correspondence to: Cliff Leek, State University of New York at Stony Brook; e-mail: cliffleek@gmail.com.
} 